\title{
Zmiany kierunków kształcenia w Akademii Ekonomicznej w Krakowie w okresie transformacji gospodarki narodowej
}

W okresie transformacji społeczno-ustrojowej na znaczeniu zyskuje wiele nowych czynników rozwoju społeczno-gospodarczego. Współcześnie za jeden z najważniejszych uznaje się pożiom nauki i szkolnictwa wyższego (Juszkiewicz 1997). Nauka wpływa na każdą sferę życia społecznego i służy ona gospodarce (Parysek 1997). Przyjmuje się, że w nowej fazie informacyjnej, do której zmierzamy, zasoby intelektualne społeczeństwa stanowią jeden z czynników wzrostu gospodarczego, zaś inwestycje służące zwiększeniu ich potencjału determinują konkurencyjność poszczególnych krajów w wymianie międzynarodowej. W związku z tym jakość systemu nauki i szkolnictwa jest czynnikiem decydującym o kierunkach i poziomie rozwoju wszystkich sektorów gospodarki, w tym szczególnie przemysłu. Dlatego we wszystkich rozwiniętych gospodarczo państwach, szkoły wyższe przystępują do mniej lub bardziej radykalnych przemian w celu przystosowania się do nowych uwarunkowań spowodowanych przez rewolucję informacyjną i związaną przez nią rewolucję naukowo-techniczną oraz wprowadzania nowych reguł zarządzania.

W Polsce w związku ze zmianami społeczno-gospodarczymi pojawiło się duże zapotrzebowanie na dobrze wykształcone kadry zarządzające, które są warunkiem osiągania sukcesu rynkowego przez przedsiębiorstwa. Powszechnie wiadomo, że poziom wymagań stawianych ludziom wdrażającym nowe rozwiązania jest wyższy od tego, jaki wystarcza do biernego wykorzystywania dotychczasowych rozwiązań.

Szkolnictwo wyższe w Polsce po 1989 roku podlega znacznym zmianom i przekształceniom zarówno w aspekcie ilościowym i jakościowym (Chojnicki, Czyż 1997). Przemiany społeczno-gospodarcze spowodowały zwiększenie zainteresowania studiami wyższymi. Są one dzisiaj postrzegane jako warunek lepszego startu życiowego, zatrudnienia i wyższych zarobków. W konsekwencji nastąpił wzrost liczby szkół wyższych z 96 w 1989 r. do 292 w 2001 r., tj. ponad trzykrotny. Towarzyszył temu wzrost liczby studentów z 0,4 mln w 1989 r. do 1,6 mln 2001 r., tj. do $400 \%$ (Tabela 1). W zasadniczym stopniu wpłynęło na to powołanie 185 uczelni niepaństwowych. W konsekwencji nastąpił spadek udziału studentów uczelni państwowych w ogólnej liczbie studentów do 70,1\%. Procesy transformacyjne, które zmieniły rynek pracy wpłynęły na przekształcenia organizacyjne w uczelniach państwowych w latach dziewięćdziesiątych. Miały one dwojakiego rodzaju charakter, po pierwsze wiązały się ze zmianami ustrojowymi, co pociągało za sobą likwidację lub reorganizację niektórych instytutów, zakładów i katedr, szczególnie w szkołach ekonomicznych oraz powstanie wielu nowych jednostek, których przedmiotem działalności są różne 
dziedziny, w tym zwłaszcza związane $\mathbf{z}$ wdrażaniem gospodarki rynkowej. Po drugie polegały one na rozszerzeniu możliwości kształcenia studentów w trybie zaocznym, wieczorowym i eksternistycznym, co wynika ze zwiększonego zapotrzebowania młodzieży na tego typu kształcenie. Szczególnie uwidoczniło się to na studiach ekonomicznych, na których pojawiły się takie specjalizacje jak logistyka ekonomiczna, samorząd terytorialny i gospodarka lokalna, bankowość, ubezpieczenia, finanse publiczne, rynki kapitałowe, badania rynku i marketing, zarządzanie marketingowe, przedsiębiorczość i innowacje, nieruchomości itp. Należy wnosić, iż te zmiany struktury kierunków kształcenia wpłyną na zwiększenie innowacyjności polskiej gospodarki, które jest niezbędnym warunkiem trwałego wzrostu gospodarczego.

Tabela 1. Rola Akademii Ekonomicznej w Krakowie w szkolnictwie wyższym w latach 1989-2000.

\begin{tabular}{|r|r|r|r|r|r|r|}
\hline & \multirow{2}{*}{ Lata } & \multirow{2}{*}{$\begin{array}{c}\text { AE } \\
\text { w Krakowie }\end{array}$} & $\begin{array}{c}\text { Ogółem } \\
\text { ekonomii }\end{array}$ & $\begin{array}{c}\text { Ogółem } \\
\text { w Polsce }\end{array}$ & $\begin{array}{c}\text { Udzial studen- } \\
\text { tów ekonomii } \\
\text { w ogólnej licz- } \\
\text { bie studentów }\end{array}$ & \multicolumn{2}{|c|}{$\begin{array}{c}\text { Udział AE w Krakowie } \\
\text { w liczbie studentów }\end{array}$} \\
\hline 1989 & 4150 & 45527 & 371049 & 12,27 & 9,12 & 1,12 \\
\hline 1990 & 4074 & 49426 & 386171 & 12,8 & 8,24 & 1,05 \\
\hline 1991 & 4479 & 58098 & 409948 & 14,17 & 7,71 & 1,09 \\
\hline 1992 & 4920 & 78657 & 476222 & 16,52 & 6,26 & 1,03 \\
\hline 1993 & 7570 & 105726 & 536790 & 19,7 & 7,16 & 1,41 \\
\hline 1994 & 9339 & 136925 & 661633 & 20,7 & 6,82 & 1,41 \\
\hline 1995 & 11830 & 181175 & 736490 & 24,6 & 6,53 & 1,61 \\
\hline 1996 & 13744 & 243708 & 905755 & 26,91 & 5,64 & 1,52 \\
\hline 1997 & 15322 & 332099 & 1070702 & 31,02 & 4,61 & 1,43 \\
\hline 1998 & 17005 & 428910 & 1247630 & 34,38 & 3,96 & 1,36 \\
\hline 1999 & 17658 & 394926 & 1425846 & 27,7 & 4,47 & 1,24 \\
\hline 2000 & 18707 & 435380 & 1578241 & 27,59 & 4,3 & 1,19 \\
\hline
\end{tabular}

Źródło: „Akademia Ekonomiczna w Krakowie w latach 1975-2000” pod red. J. M. Małeckiego, Kraków 2000, Wydawnictwo AE w Krakowie, Rocznik szkolnictwa wyższego 2001.

W świetle powyższych przesłanek podjęto problematykę zmian kierunków studiów Akademii Ekonomicznej w Krakowie, ze szczególnym uwzględnieniem okresu transformacji ustrojowej. W pracy starano się określić, w jakim stopniu zmiany kierunków kształcenia nawiązują do restrukturyzacji gospodarki narodowej.

W rankingach szkół wyższych Akademia Ekonomiczna w Krakowie zajmuje bardzo wysoką pozycję. W badaniach przeprowadzonych przez Komitet Narodowy AISEC Polska dotyczących szans zawodowych absolwentów szkół wyższych, AE w Krakowie zajmuje czwarte miejsce w ocenie studentów i trzecie w ocenie pracodawców Uczelni (po Szkole 
Głównej Handlowej w Warszawie i Akademii Ekonomicznej w Poznaniu). W publikowanym we „Wprost” rankingu wyższych szkół ekonomicznych z 1999 roku Akademia Ekonomiczna w Krakowie zajmuje drugie miejsce. W rankingu wyższych uczelni, opublikowanym w „Polityce” w kwietniu 2001 roku, spośród uczelni kształcących w zakresie ekonomii i zarządzania AE w Krakowie zajmuje trzecią pozycję po SGH w Warszawie i AE w Poznaniu.

Wydaje się, że szkolnictwo wyższe w XXI w. cechować się będzie przede wszystkim dużą elastycznością procesu kształcenia, podatną do zmian strukturą kształcenia, elastycznymi procedurami edukacyjnymi, które łatwo dostosuje się do zmiennych wymagań społeczeństwa (Dębska. Mischke 2001). Wstępnie przyjmujemy, że kierunki studiów charakteryzujące się wzrostem liczby studentów i nowo powołane nawiązują do aktualnych potrzeb rynku pracy wywołanych procesami transformacji. Natomiast likwidowane związane są ze zmniejszającym się zapotrzebowaniem na tego typu kształcenie.

W latach zmian systemu gospodarowania obserwuje się wzrost zainteresowania studiami ekonomicznymi (ryc. 1, 2). Zwiększenie zainteresowania tego typu studiami na początku lat dziewięćdziesiątych miał rozliczne uwarunkowania ekonomiczne i społeczne. Dawały one w powszechnym mniemaniu możliwość osiągnięcia sukcesu w interesach, operacjach finansowych, grze na giełdzie, wejścia w nowoczesną gospodarkę rynkową. W związku z tym liczba studentów kierunków ekonomicznych we wszystkich uczelniach w Polsce wzrosła z 45,5 tys. w 1989 r. do 435,4 tys. w 2000 r., tj. prawie dziesięciokrotnie (Tabela 1). Nastąpiło, zatem zwiększenie odsetka studentów kierunków ekonomicznych w ogólnej liczbie studentów z 12,3\% w 1989 r. do 27,6\% w 2000 r., tj. o 15,3 p.p. W świetle przeprowadzonej analizy okazuje się, że w latach 1989-2000 dynamika wzrostu studentów ekonomii była bardzo duża i wynosiła $956,3 \%$.

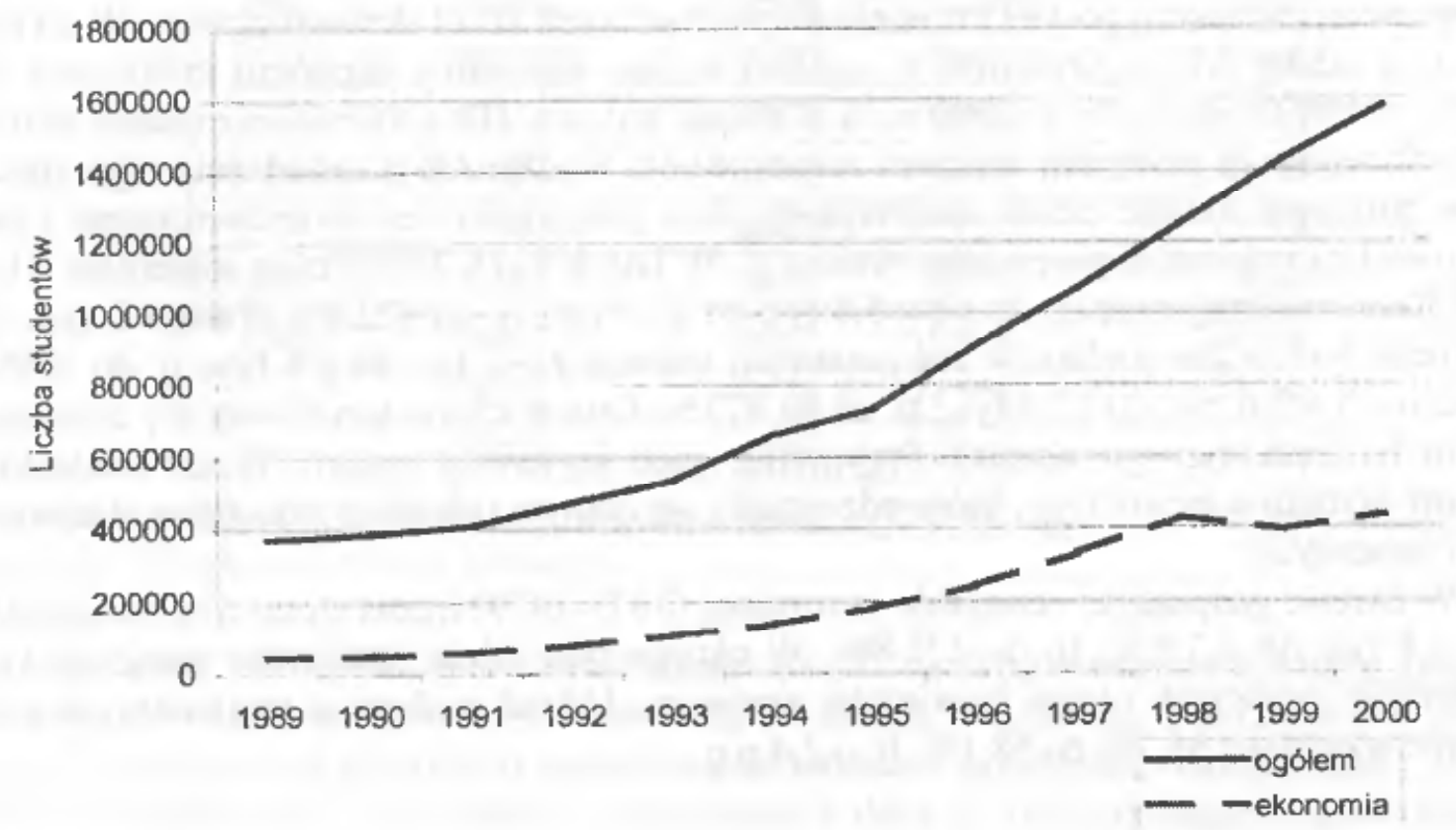

Źródło: tabela 1

Ryc. 1. Zmiany liczby studentów szkół wyższych w Polsce w latach 1989-2000 


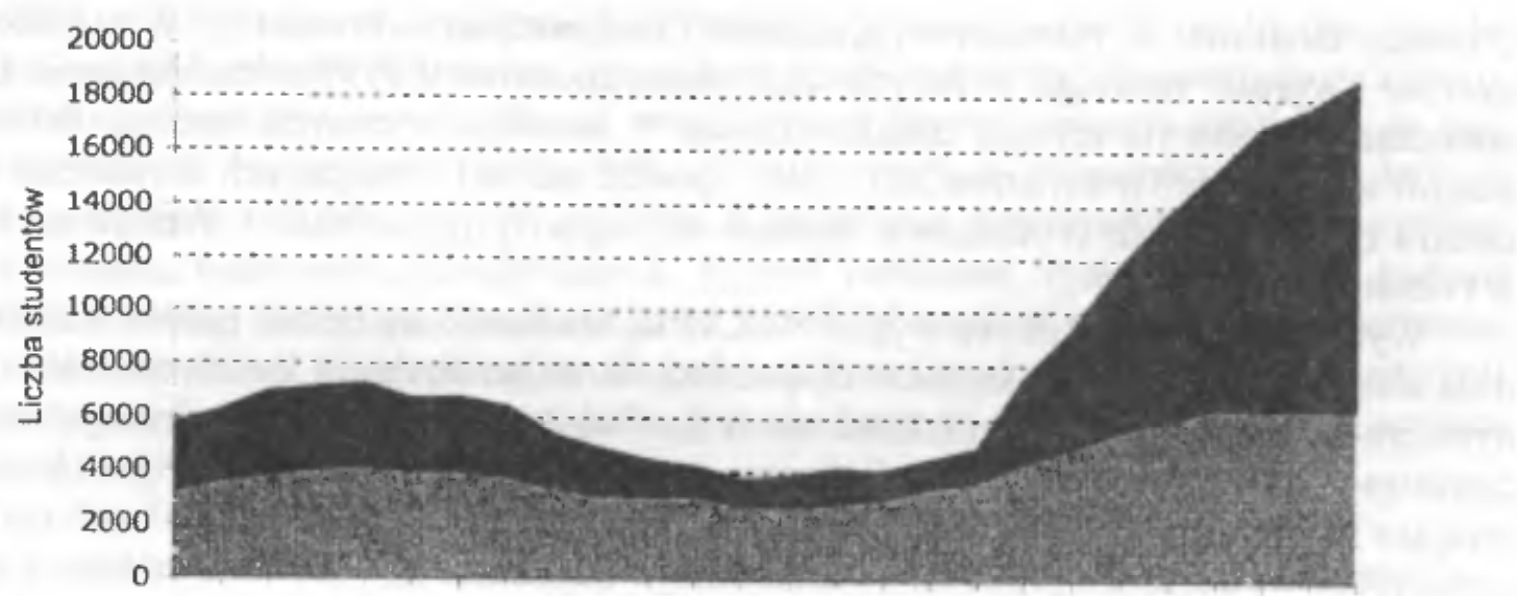

1975197719791981198319851987198919911993199519971999

Źródło: tabela 2

Ryc. 2. Zmiany liczby studentów Akademii Ekonomicznej w Krakowie w latach 1975-2000

Przyjmując jako kryterium zmiany udziału Akademii Ekonomicznej w Krakowie na rynku edukacyjnym można wyróżnić trzy okresy. Pierwszy z nich obejmuje początkowe lata transformacji gospodarki narodowej (1989-1992), kiedy zauważa się nieznaczny spadek udziału krakowskiej AE w ogólnej liczbie studentów z 1,1\% do 1,0\%. Drugi okres (1992-1995) charakteryzuje się wzrostem tego udziału z $1,0 \%$ do $1,6 \%$, a trzeci (19952000 ) ponownym spadkiem z $1,6 \%$ do $1,2 \%$. Związane jest to, jak już wspomniano z powstawaniem, zwłaszcza po 1995 r. wielu niepaństwowych szkół ekonomicznych. W związku z tym udział AE w Krakowie w ogólnej liczbie studentów ekonomii zmniejszył się z 9,1\% w 1989 r. do 4,3\% w 2000 r., tj. o ponad połowę. Dla scharakteryzowania współczesnych tendencji przemian ważnym zagadnieniem wydaje się prześledzenie tego zjawiska w dłuższym okresie czasu obejmującego lata gospodarki centralnie sterowanej i początkowe lata wdrażania gospodarki rynkowej. W latach 1975-2000 liczba studentów Akademii Ekonomicznej zwiększyła się z 5,8 tys. do 18,7 tys., tj. do 322,4\% (Tabela 2, ryc. 2). W okresie tym liczba studentów stacjonarnych wzrosła z 3,2 tys. do 6,4 tys., tj. do $200 \%$, a zaocznych z 2,6 tys. do 12,3 tys., tj. aż do $473 \%$. Lata te charakteryzowały się zróżnicowanym tempem rozwoju uczelni. Przyjmując jako kryterium zmiany liczby studentów możemy wyróżnić trzy okresy, które odznaczały się różnym udziałem studentów stacjonarnych i zaocznych.

W okresie gospodarki centralnie sterowanej (1975-1979) liczba studentów zwiększała się z 5,8 tys. do 7,3 tys., tj. do $125,8 \%$. W okresie tym udział studentów stacjonarnych i studentów zaocznych ulegał niewielkim zmianom. Udział studentów stacjonarnych nieznacznie wzrastal z $55,7 \%$ do $58,1 \%$, tj. o 2,4 p.p. 
Tabela 2. Zmiany liczby studentów Akademii Ekonomicznej w Krakowie w latach 1975-2000

\begin{tabular}{|c|c|c|c|c|}
\hline \multirow{3}{*}{ Lata } & \multicolumn{3}{|c|}{ Liczba studentów } & \multirow{3}{*}{$\begin{array}{c}\text { Udzial } \\
\text { stacjonarnych }\end{array}$} \\
\hline & \multirow{2}{*}{ ogółem } & \multicolumn{2}{|l|}{ w tym } & \\
\hline & & stacjonarni & zaoczni & \\
\hline 1975 & 5771 & 3213 & 2558 & 55,67 \\
\hline 1976 & 6267 & 3645 & 2622 & 58,16 \\
\hline 1977 & 6965 & 3838 & 3127 & 55,10 \\
\hline 1978 & 7145 & 4059 & 3086 & 56,81 \\
\hline 1979 & 7277 & 4231 & 3046 & 58,14 \\
\hline 1980 & 6708 & 3975 & 2733 & 59,26 \\
\hline 1981 & 6768 & 3990 & 2778 & 58,95 \\
\hline 1982 & 6426 & 3787 & 2639 & 58,93 \\
\hline 1983 & 5381 & 3392 & 1989 & 63,04 \\
\hline 1984 & 4872 & 3163 & 1709 & 64,92 \\
\hline 1985 & 4455 & 3106 & 1349 & 69,72 \\
\hline 1986 & 4228 & 3142 & 1086 & 74,31 \\
\hline 1987 & 3754 & 2743 & 1011 & 73,07 \\
\hline 1988 & 3891 & 2750 & 1141 & 70,68 \\
\hline 1989 & 4150 & 2883 & 1267 & 69,47 \\
\hline 1990 & 4074 & 3080 & 994 & 75,60 \\
\hline 1991 & 4479 & 3462 & 1017 & 77,29 \\
\hline 1992 & 4920 & 3694 & 1226 & 75,08 \\
\hline 1993 & 7570 & 4397 & 3173 & 58,08 \\
\hline 1994 & 9339 & 4942 & 4397 & 52,92 \\
\hline 1995 & 11830 & 5596 & 6234 & 47,30 \\
\hline 1996 & 13744 & 6023 & 7721 & 43,82 \\
\hline 1997 & 15322 & 6488 & 8834 & 42,34 \\
\hline 1998 & 17005 & 6411 & 10594 & 37,70 \\
\hline 1999 & 17658 & 6470 & 11188 & 36,64 \\
\hline 2000 & 18707 & 6416 & 12291 & 34,30 \\
\hline
\end{tabular}

Źródło: „Akademia Ekonomiczna w Krakowie w latach 1975-2000” pod red. J.M. Małeckiego, Kraków 2000, Wydawnictwo AE w Krakowie.

W latach 1975-1979 na studiach stacjonarnych funkcjonowały następujące kierunki studiów: ekonomiczno-społeczny, ekonomiki produkcji, organizacji i zarządzania, planowania i finansowania gospodarki narodowej, ekonomiki i organizacji obrotu i usług, cybernetyki ekonomicznej i informatyki, przetwarzania danych, rachunkowości i towaroznawstwa. Na studiach dla pracujących istniały następujące kierunki: ekonomika i organizacja produkcji, finanse, organizacja i zarządzanie, ekonomiczno-społeczny, ekonomika i organizacja obrotu i usług, a także organizacja i przetwarzanie danych. Najliczniejszymi kierun- 
kami w tym okresie były tradycyjne kierunki ekonomiki produkcji i obrotu, co wynikało z największego zapotrzebowania na absolwentów z ministerialnych limitów przyjęć. Do roku 1980 struktura kierunków i specjalności była w zasadzie stabilna i ulegała stosunkowo niewielkim zmianom.

Okres drugi (1980-1987) charakteryzuje się spadkiem ogólnej liczby studentów AE z 6,7 tys. do 3,8 tys., tj. do $56,7 \%$, a także wzrostem udziału studentów stacjonarnych w ogólnej ich liczbie z 59,3\% do 73,1\%, tj. do 123,3\%. Zmniejszenie zainteresowania studiami związane było z ogólną sytuacją w kraju i obniżaniem ministerialnego limitu przyjęć na I rok (Małecki 2000). Na studiach stacjonarnych limit drastycznie zmniejszono z 760 w 1981 r. do 492 w 1985 r., a następnie utrzymywano na zbližonym poziomie do końca lat osiemdziesiątych. Liczba studentów stacjonarnych zmniejszyła się zatem z 4,0 tys. do 2,7 tys., tj. do $67,5 \%$, a na zaocznych z 2,7 tys. do 1,0 tys., tj. do $37,0 \%$. Również studia zaoczne w pierwszej połowie lat osiemdziesiątych charakteryzowały się spadkiem liczby studiujących z 2,7 tys. w 1980 do 1,0 tys. w 1987 r., tj. do 37,0\% (ryc. 3). Rozważano nawet możliwość zupełnego zaniechania tej formy kształcenia. Limity przyjęć na studiach zaocznych zmniejszono z 511 w 1981 r. do 60 w 1983 r., a następnie utrzymywały się na poziomie 360. Spadek liczby studentów dotyczył wszystkich kierunków studiów, jedynie na kierunku planowanie i finansowanie gospodarki narodowej na studiach stacjonarnych zaobserwowano w tym okresie stagnację liczby studentów na poziomie około 300 .

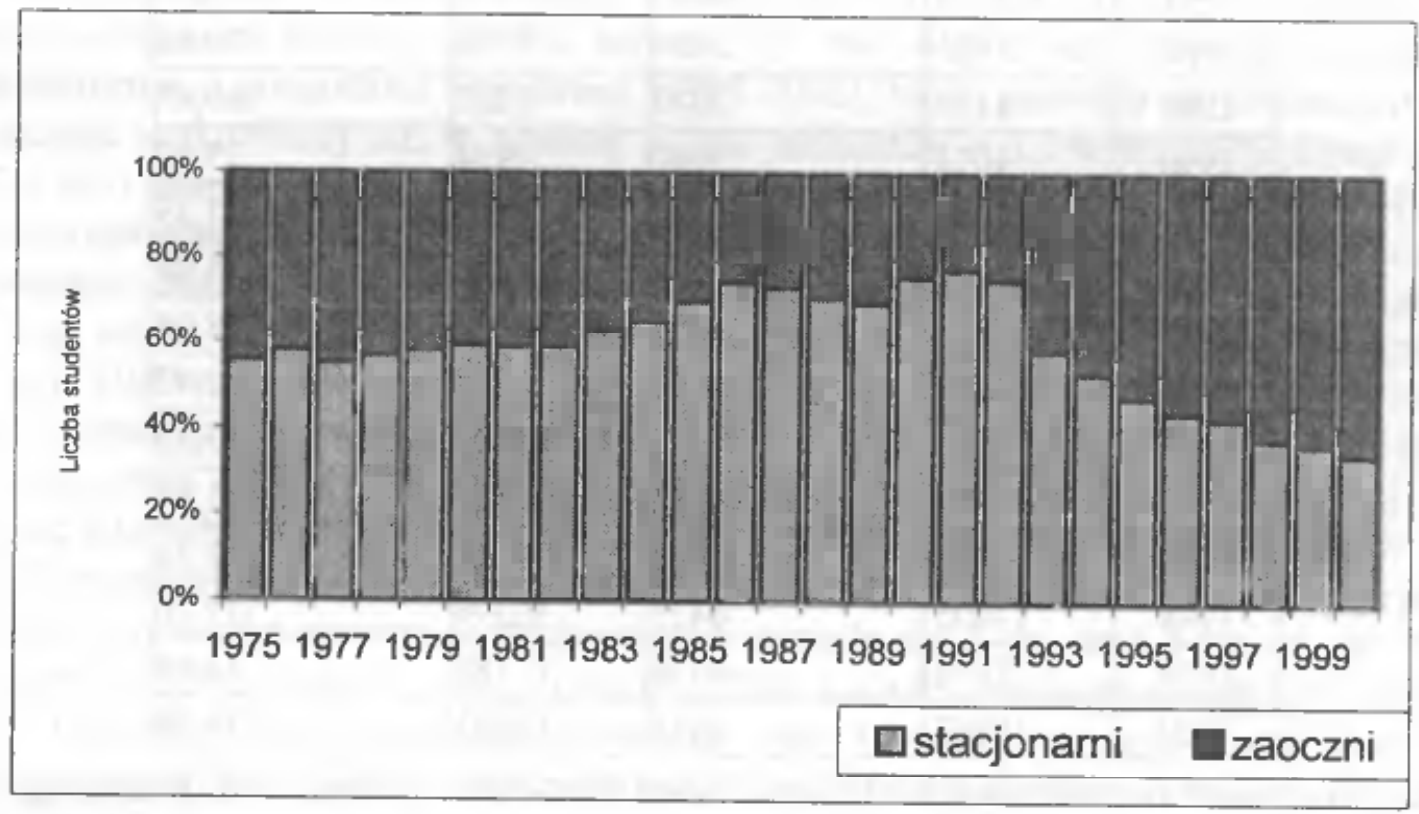

Źródło: tabela 2

Ryc. 3. Zmiany struktury kształcenia studentów Akademii Ekonomicznej w Krakowie w latach 1975 do 2000

Trzeci okres obejmujący lata transformacji gospodarki narodowej (1988-2000) charakteryzuje się intensywnym wzrostem liczby studentów od 3,9 tys. do 18,7 tys., tj. do $479,5 \%$. Zauważa się jednak, że w pierwszych latach, (1988-1992) wzrost ten był bardzo powolny z 3,9 tys. do 4,9 tys., czyli do $136,1 \%$. Natomiast po 1992 roku obserwuje się znacznie szybszy wzrost liczby studentów, z 4,9 tys. do 18,7 tys. w 2000 r., tj. prawie czte- 
rokrotny. Liczba studentów stacjonarnych w tym okresie wzrosła z 2,7 tys. do 6,4 tys., tj. do $237 \%$, a studentów zaocznych z 1,1 do 12,3 tys., tj. ponad dziesięciokrotnie. W konsekwencji systematycznie malał udział studentów stacjonarnych z 70,7\% do $34,3 \%$, tj. do $48,5 \%$.

Oznacza to, że dynamika wzrostu liczby studentów stacjonarnych była zdecydowanie mniejsza od dynamiki wzrostu liczby studentów zaocznych. W kolejnych latach udział ten zmniejszał się z 70,7\% w 1988 r. do $34,3 \%$ w 2000 r.

Konsekwencje zmian procesów gospodarowania w Polsce, które miały poważny wpływ na rozwój szkolnictwa wyższego, a przede wszystkim szkolnictwa ekonomicznego, zdominowały rozwój AE po 1989 roku (Szpak 2000). Generalna zmiana kierunków kształcenia Akademii w tym okresie wynikała $\mathrm{z}$ :

1. rosnącego zainteresowania studiami ekonomicznymi wśród młodzieży i zmiany postaw studentów wobec studiowania

2. wzrostu konkurencji na rynku edukacji ekonomicznej, wyrażającego się zakładaniem prywatnych wyższych szkół ekonomicznych oraz kierunków ekonomicznych na innych uczelniach państwowych

3. urynkowienia szkolnictwa wyższego (możliwości pobierania opłat za nauczanie)

4. konieczności dostosowania planów i programów nauczania do wymogów gospodarki rynkowej

5. autonomii szkół wyższych

Reformowanie procesów kształcenia objęło zmiany kierunków studiów, ujednolicenie planów studiów I roku, sukcesywne zmiany w programach lat wyższych, rozwój różnych form kształcenia, zmiany w programach edukacyjnych, zmiany w zasadach rekrutacji, wprowadzenie oceniania zajęć przez studentów oraz swobodnego wyboru przedmiotów i punktowego zaliczania. Celem powyższych zmian było dostosowanie programów nauczania Uczelni do wymogów gospodarki rynkowej. Modyfikacja planów studiów objęła także studia zaoczne i uzupełniające magisterskie. Rozwijały się nowe formy studiów:

- 1993 - otwarto 3-letnie studia wieczorowe (dyplom licencjata)

- 1995 - 2-letnie studia uzupełniające magisterskie ze zwiększoną liczbą godzin

- 1994 - na towaroznawstwie 3-letnie studia zawodowe dzienne

- 1995 - 3,5-letnie zawodowe zaoczne.

Zmiany te spopularyzowały studia towaroznawcze. Z dniem I marca 1992 r. na Akademii Ekonomicznej zostały utworzone nowe wydziały: Wydział Ekonomii, Wydział Zarządzania oraz na prawach wydziału Instytut Towaroznawstwa, który 11 maja 1995 r. przekształcony został w Wydział Towaroznawstwa. Wprowadzono również nowe kierunki studiów i specjalności. Kierunki kształcenia to ekonomia, finanse i bankowość, międzynarodowe stosunki gospodarcze i polityczne, zarządzanie i marketing, informatyka i ekonometria, towaroznawstwo. W 1991/1992 roku akademickim przeprofilowano bardzo wiele kierunków studiów, które nie odpowiadały na potrzeby gospodarki lub uległy przekształceniu w związku ze zmianą treści kształcenia. Były to: ekonomiczno-społeczny, organizacji i zarządzania, planowania i finansowania gospodarki narodowej, cybernetyki ekonomicznej i informatyki, ekonomiki i organizacji handlu zagranicznego, ekonomiki i organizacji produkcji, ekonomiki i organizacji obrotu i usług. Pod koniec lat osiemdziesiątych i na początku lat dziewięćdziesiątych zwiększyło się zainteresowanie następującymi kierunkami studiów: cybernetyką ekonomiczną i ekonomiką i organizacją handlu zagranicznego na studiach stacjonarnych, a także ekonomiką i organizacją produkcji na studiach zaocznych. Stagnującą liczbą studentów ce- 
chowała się ekonomika i organizacja obrotu i usług na studiach stacjonarnych (ryc. 4, 5). Na pozostałych kierunkach studiów obserwowano spadek liczby studentów. Po roku 1995 nastąpiła kolejna reorganizacja struktury kierunków kształcenia. Na Wydziale Ekonomii znacząco wzmocniły się katedry związane z organizacją i zarządzaniem. Umocnił się także Wydział Towaroznawstwa, a na Wydziale Zarządzania katedry marketingowe. W latach 1996-2000 Uczelnia poszerzyła zakres studiów o nowy kierunek: "gospodarka przestrzenna" (1997/1998) i nowe specjalności „strategie rozwoju regionalnego”, „zarządzanie miastem”, "międzynarodowe stosunki gospodarcze”, „ubezpieczenia gospodarcze” (1999/2000), zmieniono również nazwę specjalności „zarządzanie zasobami pracy” na „zarządzanie zasobami ludzkimi”. Od 15 lutego 2002 r. planowane jest utworzenie specjalności „euromarketing”.

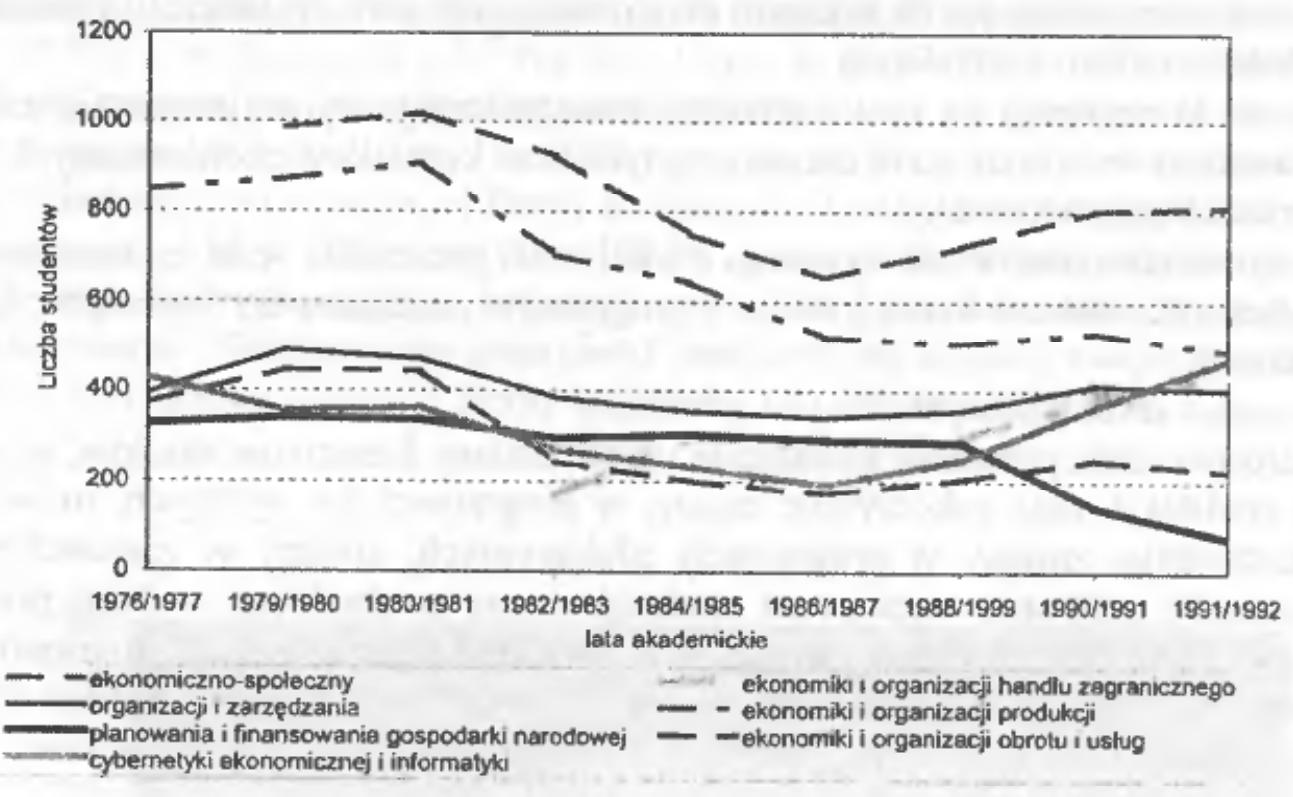

Źródło: tabela 3.

Ryc. 4. Zmiany liczby studentów stacjonarnych Akademii Ekonomicznej w Krakowie na kierunkach zlikwidowanych do $1991 \mathrm{r}$.

Analizując zmiany liczby studentów na poszczególnych kierunkach studiów w latach 1990-2001 naležy stwierdzić, że przez cały ten okres najpopularniejszymi kierunkami studiów były: zarządzanie i marketing, finanse i bankowość, a na studiach stacjonarnych również międzynarodowe stosunki gospodarcze i polityczne (Tabela 3,4). Jednakże względu na różne tendencje zmian liczby studentów wyróżnić dwa okresy.

Lata 1990-1998 charakteryzowały się wzrostem liczby studentów AE z 4,9 tys. do 17,0 tys., tj. do $347,9 \%$. Na studiach stacjonarnych liczba studentów wzrosła z 3,4 tys. do 5,5 tys., tj. do $183,3 \%$ Natomiast na studiach zaocznych dopiero od 1992 r. obserwuje się wzrost liczby studentów z 734 do 7,4 tys., tj. dziesięciokrotny. Okres ten charakteryzuje się zatem dużą dynamiką wzrostu zwłaszcza liczby studentów zaocznych. Na studiach zaocznych w tym okresie na wszystkich kierunkach studiów wzrastała liczba studentów. Największa dynamika wzrostu dotyczyła zarządzania i marketingu i finansów i bankowości. Na zarządzaniu i marketingu liczba studentów zwiększyła się z 394 do 3149 tj. do ośmiokrotnie, a na finansach i bankowości ze 197 do 1424, tj. ponad siedmiokrotnie (Tabela 4, ryc. 5). 


\begin{tabular}{|c|c|c|c|c|c|c|c|c|c|c|c|c|c|c|c|c|c|c|}
\hline \multirow{2}{*}{ Kierunki studiów } & \multicolumn{18}{|c|}{ Liczba studentów w latach akademickich } \\
\hline & $1976 / 1977$ & 7 1979/1980 & ] 1980/198! & $1982 / 1983$ & 1984/1985 & $1986 / 1987$ & $1988 / 1989$ & $9,1990 / 1991$ & $1991 / 1992$ & $\begin{array}{ll}2 \mid 1992 / 1993 \\
\end{array}$ & $31993 / 1994$ & $41994 / 1995$ & $51995 / 1996$ & $6 \mid 1996 / 1991$ & $71997 / 1998$ & 319981.999 & $9 \mid 1999 / 2000$ & 0020002001 \\
\hline Ogólem & 3846 & 3991 & 4009 & 3392 & 3106 & 2731 & 2865 & 3431 & 3649 & 4334 & 4865 & 5421 & 5701 & 6029 & 5808 & 5764 & 5616 & 5483 \\
\hline Studium Podstawowe & & & & & & & & & & 1067 & 109 & 1098 & 1064 & 1084 & 1037 & 1066 & 973 & 1077 \\
\hline Wydzial Ekonomii & & & & & & & & 2029 & 2104 & 1592 & 1776 & 1998 & 2267 & 2584 & 2755 & 2829 & 2917 & 2785 \\
\hline Ekonomika handlu wew. & 891 & & & & & & & & & & & & & & & & & \\
\hline Ekonomika budownictwa & 25 & & & & & & & & & & & & & & & & & \\
\hline Ekonomiczno-spoleczny & 372 & 446 & 443 & 244 & 202 & 174 & 206 & 250 & 223 & & & & & & & & & \\
\hline $\begin{array}{l}\text { Ekonomiki i organizacji } \\
\text { handlu zagranicznego }\end{array}$ & & & & 167 & 299 & 289 & 300 & 385 & 439 & & & & & & & & & \\
\hline organizacji i zarzadzania & 394 & 491 & 470 & 386 & 356 & 343 & 359 & 415 & 404 & & & & & & & & & \\
\hline $\begin{array}{l}\text { ekonomiki } \\
\text { i organizacji produkcji } * *\end{array}$ & 848 & 872 & 909 & 704 & 644 & 522 & 507 & 532 & 489 & & & & & & & & & \\
\hline $\begin{array}{l}\text { planowaniania i finansow wania } \\
\text { gospodarki narodowej }\end{array}$ & 327 & 341 & 338 & 296 & 305 & 294 & 287 & 143 & 75 & & & & & & & & & \\
\hline gospodarki regionalnej & & & & & & & & 90 & 133 & & & & & & & & & \\
\hline Anansow i bankowości *.. & 36 & & & & & & & 214 & 341 & 369 & 547 & 736 & 391 & 1141 & 1163 & 1115 & 1116 & 1008 \\
\hline kkonomii & & & & & & & & & & 814 & 808 & 739 & 783 & 609 & 621 & 667 & 683 & 696 \\
\hline $\begin{array}{l}\text { międzynarodowych } \\
\text { stosunków gospodarczych } \\
\text { politycanych * }\end{array}$ & & & & & & & & & & 382 & 421 & 523 & 593 & 834 & 939 & 978 & 1022 & 950 \\
\hline gospodarka przestrzenna & & 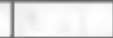 & & & & & & & & & & & & & 32 & 69 & 96 & 131 \\
\hline Wydzial zarzadzania & & & & & & & & 1171 & 1285 & 1479 & 1837 & 2180 & 2268 & 2315 & 1984 & 1875 & 1726 & 1621 \\
\hline $\begin{array}{l}\text { ekonomiki i organizacji } \\
\text { obrotu i uslug }\end{array}$ & & 987 & 1020 & 924 & 752 & 655 & 725 & 803 & 811 & & & & & & & & & \\
\hline $\begin{array}{l}\text { cybermetyki ekonomicanej } \\
\text { i informatyki }\end{array}$ & 428 & 356 & 364 & 272 & 234 & 194 & 249 & 368 & 474 & & & & & & & & & \\
\hline zarzadzania i marketingu & & & & & & & & & & 1220 & 1619 & 1936 & 2083 & 2136 & 1852 & 1747 & 1585 & 1463 \\
\hline jinformatyki i ekonometrii & & & & & & & & & & 259 & 218 & 244 & 185 & 179 & 132 & 128 & 141 & 158 \\
\hline Wydzial towaroznawstwa & 528 & 498 & 465 & 427 & 314 & 257 & 232 & 231 & 260 & 196 & 143 & 145 & 100 & 46 & 32 & & & \\
\hline
\end{tabular}

- od 1999/2000 roku akademickiego - stosunki międzynarodowe

* - ekonomika produkcji w 1976 roku

*** - finanse w 1976 roku

Źródło: Opracowanie własne na podstawie formularzy sprawozdawezych GUS S-10 i S-11. 
Liczba studentow w latach akademickich

\begin{tabular}{|c|c|c|c|c|c|c|c|c|c|c|c|c|c|c|c|c|c|c|}
\hline \multirow{2}{*}{ Kierunki studiów } & \multicolumn{18}{|c|}{ 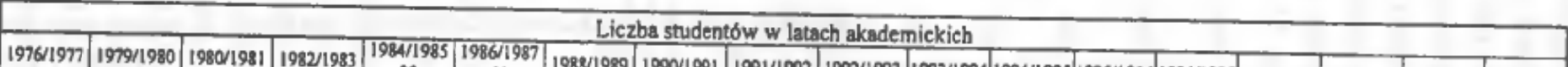 } \\
\hline & 1976/1977 & 1979/1980 & 1980/1981 & 1982/1983 & $\begin{array}{c}1984 / 1985 \\
. .\end{array}$ & $\begin{array}{c}1986 / 1987 \\
*\end{array}$ & 1988/1989 & $1990 / 1991$ & $1991 / 1992$ & $1992 / 1993$ & $1993 / 1994$ & $1994 / 1995$ & $1995 / 1996$ & $1996 / 1997$ & $1997 / 1998$ & $1998 / 1999$ & $1999 / 2000$ & 20002001 \\
\hline Ogbiem & 2801 & 2449 & 2536 & 1795 & 1041 & 763 & 860 & 800 & 734 & 2885 & 4021 & 5684 & 6820 & 7067 & 7407 & 7112 & 6848 & 6742 \\
\hline Studium Podstawourt & & & & & & & & & & & & 2557 & 2387 & 2188 & 2069 & 1825 & 1829 & 1866 \\
\hline $\begin{array}{l}\text { Wydzayl Ekooomii } \\
\text { Ekonomiki handlu }\end{array}$ & & & & & & & & 452 & 509 & 261 & 582 & 1088 & 1527 & 1705 & 1860 & 1778 & 1665 & 1591 \\
\hline $\begin{array}{l}\text { ketonomikik handlu } \\
\text { wewnegranego }\end{array}$ & 9009 & & 150 & & & & & & & & & & & & & & & \\
\hline kkonomiczno-spoteczny & 29 & 73 & 83 & 33 & & & & & & & & & & & & & & \\
\hline $\begin{array}{l}\text { Ekonomiki i organizacji } \\
\text { budownictwn }\end{array}$ & 101 & 6 & 66 & & & & & & & & & & & & & & & \\
\hline organizacij i zarzadzania & $2 !$ & 69 & 85 & 86 & 27 & 28 & 97 & 148 & 97 & & & & & & & & & \\
\hline 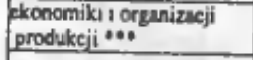 & 1613 & 611 & 636 & 870 & 393 & 272 & 285 & 194 & 349 & & & & & & . & & & \\
\hline ekonomika presmysiu & & 462 & 423 & & & & & & & & & & & & & & & \\
\hline finanstw i baykowosei * & 128 & 76 & 86 & 69 & 24 & 106 & 163 & 110 & 63 & 197 & 499 & 929 & 1218 & 1371 & 1423 & 1329 & 1163 & 1042 \\
\hline inanssw i ractunkowost & & 1 & & & & & & & & & & & & & & & & \\
\hline Ekonomii & & & & & & & & & & 64 & 83 & 159 & 309 & 334 & 437 & 449 & 502 & 549 \\
\hline Wydzial zarzadrania & & & & & & & & 348 & 225 & 394 & 1162 & 2039 & 2845 & 3019 & 3179 & 3071 & 2841 & 2677 \\
\hline $\begin{array}{l}\text { Ekonomiki i orgenizacij } \\
\text { obrotu i ushyg. }\end{array}$ & & 1047 & 901 & 693 & 530 & 357 & 342 & 247 & 199 & & & & & & & & & \\
\hline aradzunis i marketingu & & & & & & & & & & 394 & 1124 & 1964 & 2788 & 2980 & 3149 & 3011 & 2778 & 2581 \\
\hline nformaykiki i ekonometrii & & & & & & & & & & & 38 & 75 & 57 & 39 & 11 & 60 & 63 & 96 \\
\hline 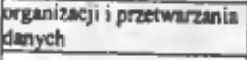 & & 98 & 87 & 44 & & & & 27 & 26 & & & & & & & & & \\
\hline Wydzial tomaroznewsen & & & & & 17 & & & & & & & & 61 & 155 & 299 & 438 & 513 & 608 \\
\hline
\end{tabular}

* - finanse i rachunkowość od 1982- 1989 roku, finanse w 1976, 1990, 1991 r

* - dla pracujących

*** - ekonomika produkcji w 1976 roku

Źródło: Opracowanie wlasne na podstawie formularzy sprawozdawczych GUS S-10 i S-11. 




Źródło: tabela 4.

Ryc. 5. Zmiany liczby studentów zaocznych Akademii Ekonomicznej w Krakowie w latach 1976 do $2000 \mathrm{r}$.

Liczba studentów stacjonarnych na kierunku zarządzanie i marketing w tym czasie wzrosła z 1220 do 2136, tj. do 175,1\%, finansów i bankowości z 369 do 1141 osób, tj. do 309,2\%, międzynarodowych stosunków gospodarczych i politycznych z 382 do 609, tj. o 118\% (Tabela 3, ryc. 6). Natomiast spadkiem liczby studentów charakteryzowały się ekonomia z 814 do 609, tj. do $74,8 \%$, a także informatyka i ekonometria z 259 do 179 , tj. do $69,1 \%$.

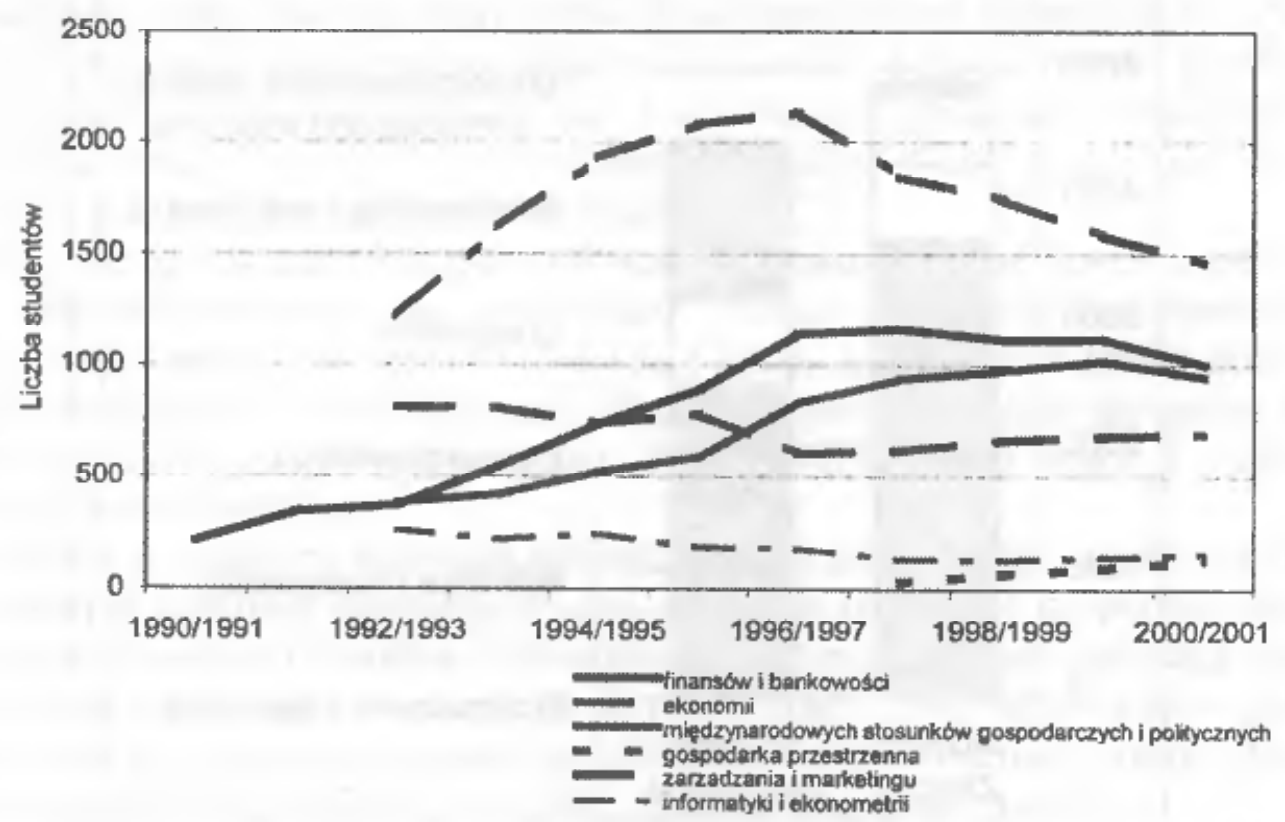

Źródło: tabela 3.

Ryc. 6. Zmiany liczby studentów stacjonarnych Akademii Ekonomicznej w Krakowie na nowych kierunkach studiów w latach 1990-2000 
Lata 1998-2001 charakteryzowały się spadkiem liczby studentów na najpopularniejszych dotychczas kierunkach studiów. W latach 1998-2001 ogólna liczba studentów AE zwiększyła się z 17 tys. do 18,7 tys., tj. do $110 \%$. Na studiach stacjonarnych na zarządzaniu i marketingu liczba studentów zmniejszyła się z 2136 do 1463, tj. do $68,4 \%$, a na finansach i bankowości z 1141 do 1008 , tj. do $88,3 \%$. Natomiast na ekonomii, która w pierwszym okresie cechowała się spadkiem liczby studentów, obserwuje się teraz ich wzrost z 609 do 696 , tj. do $114,3 \%$. Wzrastało również zainteresowanie nowo powołanym w 1997/1998 roku akademickim kierunkiem „gospodarką przestrzenną", gdzie liczba studentów zwiększyła się z 32 do 131 , tj. do $409,4 \%$. Nieznaczny wzrost liczby studentów dotyczył również informatyki i ekonometrii. W tym okresie również na studiach zaocznych na zarządzaniu i marketingu liczba studentów zmniejszyła się z 3149 do 2581 , tj. do $82,0 \%$, a na finansach i bankowości z 1423 do 1042 , tj. do $73,2 \%$. Natomiast na pozostałych kierunkach liczba studentów wzrosła, na towaroznawstwie z 61 do 608 , tj. prawie dziesięciokrotnie, na informatyce i ekonometrii z 11 do 96 , tj. ponad ośmiokrotnie a na ekonomii z 437 do 549 , tj. do $125,6 \%$.

W 2000/2001 roku akademickim największa liczba studentów stacjonarnych (1463), mimo obserwowanego od 1996/1997 roku akademickiego spadku zainteresowania tym kierunkiem, kształci się nadal na zarządzaniu i marketingu (Tabela 3). Stanowią oni $32 \%$ wszystkich studentów stacjonarnych (ryc. 7). Kolejnymi pod tym względem kierunkami studiów są finanse i bankowość (23\%) i międzynarodowe stosunki gospodarcze i polityczne $(22 \%)$.

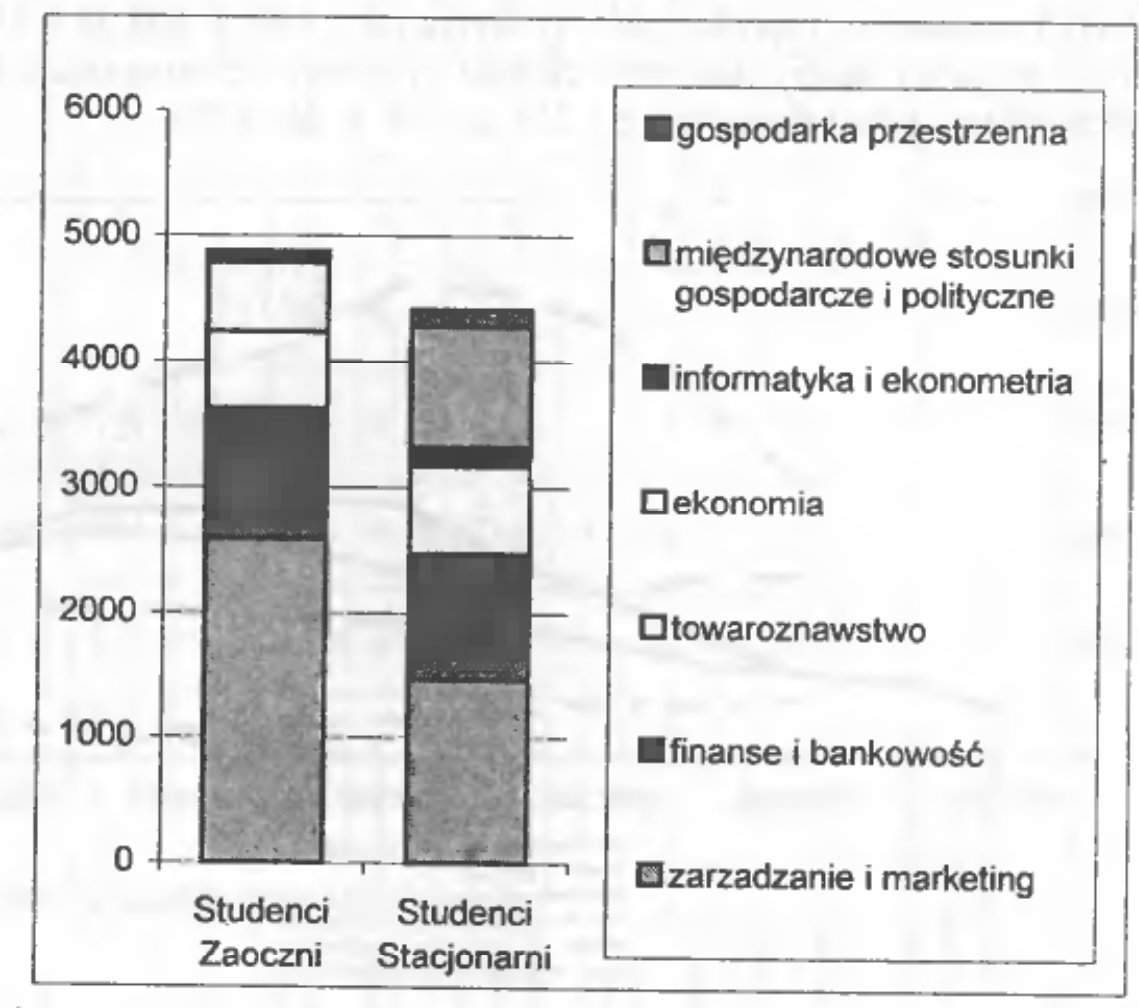

Źródło: tabela 3, 4.

Ryc. 7. Studenci Akademii Ekonomicznej w Krakowie według studiów w roku akademickim 2000/2001 
Na studiach zaocznych, podobnie jak na stacjonarnych najliczniejszym kierunkiem jest zarządzanie i marketing, na którym studiuje 2581 osób, tj. 54\% studentów zaocznych. a także finanse i bankowość, na którym to kierunku studenci stanowią $21 \%$ wszystkich studentów zaocznych (Tabela 4, ryc. 7).

Studenci AE podchodzą bardzo pragmatycznie do studiów, preferują specjalności pomagające $w$ odnalezieniu się na rynku pracy, a także nabycie uprawnień państwowych do wykonywania zawodu czy prowadzenia własnej firmy. Na kierunku ekonomii studenci preferują ekonomikę nieruchomości i inwestycji, na finansach i bankowości - finanse przedsiębiorstw, na zarządzaniu i marketingu - rachunkowość. W ostatnich sześciu latach obserwuje się przesunięcie zainteresowań z bankowości na finanse przedsiębiorstw i z marketingu na rachunkowość. Odpowiedzią Uczelni na wzmożone zainteresowanie studentów rachunkowością było podjęcie decyzji o utworzeniu od 2001/2002 roku akademickiego nowej specjalności „rewizja finansowa” na kierunku finanse i bankowość.

Należy również wspomnieć o jednej z najbardziej popularnych form uzupełniania kwalifikacji zawodowych, a mianowicie o studiach podyplomowych, które są coraz częściej podejmowane przez absolwentów w celu zwiększenia własnej konkurencyjności na rynku pracy. Podyplomowe studia Akademii Ekonomicznej organizuje Szkoła Przedsiębiorczości i Zarządzania AE oraz Małopolska Szkoła Administracji Publicznej. Szkoła Przedsiębiorczości i Zarządzania AE oferuje studia podyplomowe obejmujące 34 kierunki. Prowadzone przez Szkołę programy nauczania - stale modyfikowane na podstawie analizy rynku pracy- dostosowywane są do standardów zachodnoeuropejskich (Paszek 2001). Największą popularnością cieszą się bankowość, ekonomika i zarządzanie firmami, marketing, handel zagraniczny, rachunkowość i finanse oraz szacowanie nieruchomościami. Szkoła jest także współorganizatorem trzech nowych kierunków studiów z zakresu Internetu w biznesie - projektowanie i tworzenie aplikacji internetowych, administrowanie i zabezpieczenia systemów oraz zarządzanie przedsięwzięciami internetowymi. Za najbardziej prestiżowe uznawane są studia „Master of Business Administration” (dyplom uznawany na całym świecie). Małopolska Szkoła Administracji Publicznej prowadzi międzynarodowe studia „Master of Public Administration”, a także studia w zakresie zarządzania administracją publiczną oraz gospodarki przestrzennej.

Wzrost liczby absolwentów postawił przed Uczelnią zadanie umożliwienia pełnego wykształcenia akademickiego dla absolwentów studiów zawodowych, promowania studentów na rynku pracy, jak również zwiększył presję na śledzenie losów absolwentów w sposób systematyczny i zorganizowany. Planowane jest utworzenie specjalnej jednostki organizacyjnej zajmującej się problemami rozeznawania rynku pracy i pośrednictwa w zatrudnianiu absolwentów.

W świetle powyższych rozważań stwierdza się, że nowe profile kształcenia Akademii Ekonomicznej w Krakowie nawiązują do zmieniających się potrzeb gospodarki narodowej, procesów restrukturyzacji i integracji ekonomicznej Europy, a zatem ułatwiają dostosowanie się jej absolwentów do zmieniającego się rynku pracy. Obserwuje się szczególne zainteresowanie wśród studentów studiami na kierunkach ekonomicznych, które odpowiadają na potrzeby gospodarki rynkowej, związane z transformacją ustrojową. 


\section{Literatura}

Chojnicki Z., Czyż T., 1997, Struktura przestrzenna nauki w Polsce, Bogucki Wydawnictwo Naukowe, Poznań.

Dębska A., Mischke J., 2001, Dydaktyka XXI wieku, Materiały sympozjum naukowego zorganizowanego przez Szkołę Przedsiębiorczości i Zarządzania Akademii Ekonomicznej w Krakowie (Kraków, 14 IX 2001), Wydawnictwo AE w Krakowie.

Juszkiewicz N., 1997, Nauka i technika jako czynniki rozwoju Poznania, UAM, Poznań.

Małecki, J. M., 2000, Akademia Ekonomiczna w okresie narastajqcych trudności gospodarczych 1975-1980, [w:] Akademia Ekonomiczna w latach 1975-2000, red. J. M. Małecki, Wydawnictwo AE w Krakowie.

Małecki, J.M., 2000, Wobec kryzysu gospodarczego i spolecznego 1980-1988, [w:] Akademia Ekonomiczna w latach 1975-2000, red. J. M. Małecki, Wydawnictwo AE w Krakowie.

Parysek J., 1997, Podstawy gospodarki lokalnej. Wydawnictwo Naukowe UAM.

Paszek Z., 2001, Dydaktyka XXI wieku, Materiały sympozjum naukowego zorganizowanego przez Szkołę Przedsiębiorczości i Zarządzania Akademii Ekonomicznej w Krakowie (Kraków, 14 IX 2001), Wydawnictwo AE w Krakowie.

Szpak J., 2000, Akademia Ekonomiczna w okresie przelomu politycznego 1989-1990, [w:] Akademia Ekonomiczna w latach 1975-2000, red. J. M. Małecki, Wydawnictwo AE w Krakowie. 